\title{
A Highly Hg(II)-selective Chemosensor with Unique Diarylethene Fluorophore
}

\author{
Heesun Ji, Jinho Kim, Jung Whan Yoo, ${ }^{\dagger}$ Hyeong Seok Lee, ${ }^{\dagger}$ Ki-Min Park, ${ }^{\ddagger *}$ and Youngjin Kang** \\ Department of Chemistry and Division of Science Education, Kangwon National University, Chuncheon 200-701, Korea \\ *E-mail:kangy@kangwon.ac.kr \\ ${ }^{\dagger}$ Composite Materials Team, Korea institute of Ceramic Engineering and Technology, Seoul 153-801, Korea \\ ${ }^{\star}$ Department of Chemistry \& Research Institute of Natural Science, Gyeongsang National University, Jinju 660-701, Korea \\ *E-mail: kmpark@gnu.ac.kr \\ Received February 8, 2010, Accepted February 28, 2010
}

Key Words: Perfluorocyclopentene, Chemosensor, Mercury(II), Azacrownether

Mercury and its ion are considered as one of dangerous and wide spread global pollutants. Mercury brings about a vast of contamination in our life because of its long term residence in air and its oxidation to water soluble $\mathrm{Hg}^{2+}$. Recently the tools used for detecting mercury are atomic spectroscopy, inductively coupled plasma mass spectroscopy, and absorption/emission spectroscopy and so forth. ${ }^{2}$ These methods, however, require expensive and sophisticated instrumentations. These facts provide motivation to develop new and cheap probes for the detection of mercury ion from our environmental samples. Fluorescent chemosensors for monitoring $\mathrm{Hg}^{2+}$ have many advantages, such as low cost, simple instrumentations and high selectivity, as compared to other techniques. ${ }^{3}$ Therefore, the development of chemosensors become attractive subjects to organic/inorganic chemists.

Recently, macrocyclic fluorescent chemosensor based on crown ether have been intensively studied for application in many areas due to their selectivity for transition metals ions. ${ }^{4}$ Due to the softness of mercury ions, $\mathrm{Hg}^{2+}$, macrocycles to selective mercury ions mainly are consisted of N-S and/or O-S donor sets in receptor segment. ${ }^{3 \mathrm{~b}, 5}$ Macrocycles including NO donor set also show high selectivity to alkali metal ions. Meanwhile, the reports on the selectivity of mercury ions using this kind of donor set can hardly be found. ${ }^{6}$ Fluorophore plays an important role in fluorescent chemosensors since it evolves a detecting signal (fluorescence) upon metal recognition of macrocycles. For this reason, anthracene derivatives with high quantum efficiency are mainly used as fluorophore in fluorescence chemosensors. ${ }^{7}$ In the course of our development on the luminescent materials for use in varied applications, ${ }^{8}$ we found that diaryl- ethene compounds have shown much higher quantum efficiency than even 9,10-diphenylanthracene $\left(\Phi_{\mathrm{PL}}=0.95\right)$ due to their molecular rigidity and the presence of varied intermolecular interactions. In this regard, we envisioned that diarylethene composed of azacrownether as a receptor and of two fluorenes, which are linked by perfluorocyclopentene, as a fluorophore would show a unique photophysical properties and metal recognition. Herein, we report our systematic investigation into photophysical and coordinative properties to varied metal ions of 1,2-bis \{9,9-diethyl-7-(1,4,7,10-tetraoxa-13-azacyclopentadecane)fluoren-2-yl \}-3,3,4,4,5,5-hexafluorocyclopentene ( $\left.\mathbf{L}_{\mathbf{1}}\right)$.

As shown in Scheme 1, starting materials $\mathbf{1}$ and $\mathbf{2}$ were prepared as previously reported. ${ }^{8 \mathrm{a}, 9}$ Details of synthetic procedures of $\mathbf{1}$ and $\mathbf{2}$ are described in experimental section. The target ligand $\mathbf{L}_{\mathbf{1}}$ was prepared by the reaction of 2-bromo-9,9-diethyl7-iodofluorene (2) and 1-aza-15-crown-5 in the presence of 2-dicyclohexylphosphino-2'-( $N, N$-dimethylamino)biphenyl, $\mathrm{Pd}_{2}(\mathrm{dba})_{3}$, and sodium tert-butoxide. This ligand was fully characterized by varied spectroscopic methods.

The photophysical properties of $\mathbf{L}_{1}$ were measured in $\mathrm{CH}_{3} \mathrm{CN}$. In emission spectrum of free ligand (Figure 1 inset), a broad emission band was observed at $600 \mathrm{~nm}$ (excitation at $383 \mathrm{~nm}$ ). Interestingly, emission band of $\mathbf{L}_{1}$ is much red shifted as compared to that of compound $\mathbf{2}$. Compound $\mathbf{2}$ exhibits strong emission band with $\lambda_{\max } 450 \mathrm{~nm}$, while emission maximum of ligand $\mathbf{L}_{1}$ appears at $600 \mathrm{~nm}$ with less intensity (See supporting information). This fact suggests that the introduction of azacrown moiety may have significantly influenced on the electronic transition.

Under the same experimental conditions (i.e. the same con-

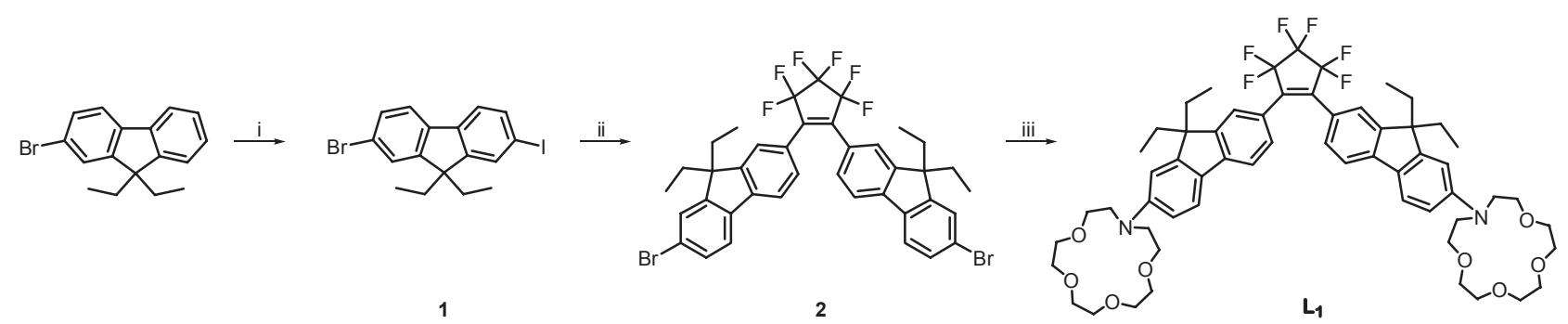

Scheme 1. Synthetic routes of $\mathbf{L}_{1}$ and reagents and experimental conditions: i) $\mathrm{I}_{2}, \mathrm{HIO}_{4}, \mathrm{CH}_{3} \mathrm{COOH} / \mathrm{H}_{2} \mathrm{O} / \mathrm{H}_{2} \mathrm{SO}_{4}$, reflux, $10 \mathrm{~h}$. ii) $n$ - $\mathrm{BuLi} / \mathrm{Ether}$, octafluorocyclopentene, $12 \mathrm{~h}$. iii) 1-aza-15-crown-5, $\mathrm{NaO}^{t} \mathrm{Bu}, \mathrm{Pd}_{2}(\mathrm{dba})_{3}, \mathrm{C}_{26} \mathrm{H}_{36} \mathrm{NP} /$ Toluene, reflux, $24 \mathrm{~h}$ 


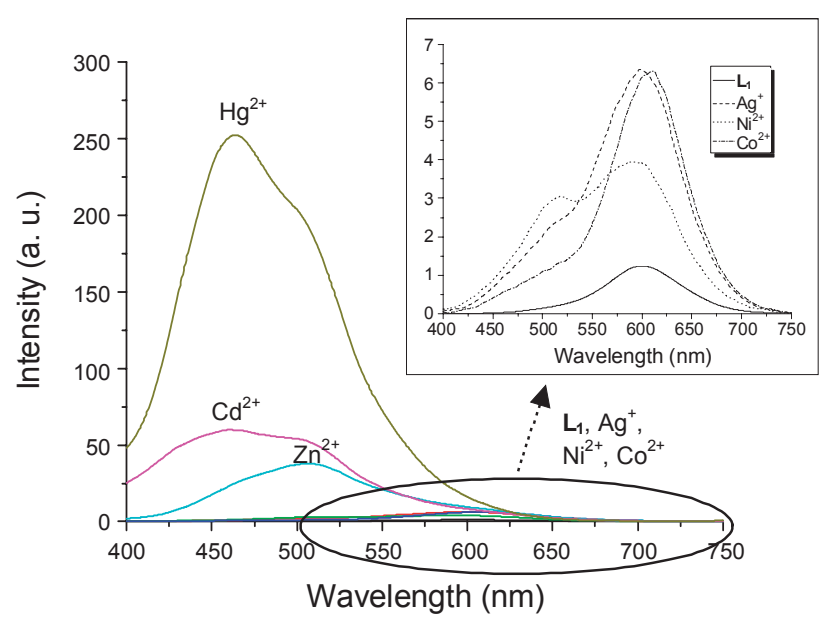

Figure 1. Change in fluorescent emission spectra of $\mathbf{L}_{1}(100 \mu \mathrm{M})$ in $\mathrm{CH}_{3} \mathrm{CN}$ in the presence of 50 equiv $\mathrm{Hg}^{2+}, \mathrm{Cd}^{2+}, \mathrm{Zn}^{2+}, \mathrm{Ni}^{2+}, \mathrm{Co}^{2+}$, and $\mathrm{Ag}^{+}$.

centration), the absorption spectrum of $\mathbf{L}_{1}$ shows the same trend (much red-shifted: $c a .70 \mathrm{~nm}$; See supporting information). These absorption and emission observed for $\mathbf{L}_{\mathbf{1}}$ are likely to due to intramolecular charge transfer (lone pair of nitrogen atom on azacrown ether to fluorene). The emission quantum yield of $\mathbf{L}_{1}$ was determined by using rhodamine $6 \mathrm{G}(0.94)$ as reference. This value is 0.035 , which is much lower than that of reference. This observation implies that an effective fluorescent quenching of excited state caused by the lone pair electron of receptor moiety, photo-induced electron transfer (PET), occurs prior to metal ion recognition. Figure 1 exhibits fluorescent emission changes of $\mathbf{L}_{\mathbf{1}}$ after addition of 50 equivalent of metal nitrate. It is interesting that the strong intense emission peak was observed in the presence of $\mathrm{Hg}$ (II) ion as compared to those of other metal ions.

To investigate the metal-induced fluorescent change of $\mathbf{L}_{\mathbf{1}}$ in the presence of metal ions such as $\mathrm{Ag}(\mathrm{I}), \mathrm{Ni}(\mathrm{II}), \mathrm{Co}(\mathrm{II}), \mathrm{Zn}(\mathrm{II})$, $\mathrm{Hg}(\mathrm{II})$, and $\mathrm{Cd}(\mathrm{II})$, we carried out titration experiments. The fluorescent enhancement effect upon metal complexation was observed for $\mathbf{L}_{\mathbf{1}}$ in the presence of metal ions investigated, but the intensity of this $\mathrm{CHEF}$ (Chelating Enhancement of Fluorescence) effect was different in all of them (Figure 1). The most effective enhancement was upon $\mathrm{Hg}^{2+}$ complexation, after addition of two equivalents the intensity of emission was reached in $252\left[I / I_{0}\right]\left(\left[I / I_{0}\right]\right.$ value is the ratio of fluorescence intensity in the presence $(I)$ and absence $\left(I_{0}\right)$ of metal ions). While after addition of 50 equivalents $\left[I / I_{0}\right]$ values for $\mathrm{Ni}^{2+}, \mathrm{Ag}^{+}, \mathrm{Co}^{2+}, \mathrm{Zn}^{2+}$ and $\mathrm{Cd}^{2+}$ were $4,6,6,38$ and 60 , respectively. These results suggest a stronger complexation with $\mathrm{Hg}^{2+}$ when compared to the other metals. As shown in Figure 2, intensity change is observed that the band at $464 \mathrm{~nm}$ reaches a plateau upon the addition of 2 equiv of $\mathrm{Hg}^{2+}$, confirming the formation of a $1: 2$ $\left(\mathrm{L}_{1}: \mathrm{M}^{2+}\right)$ complex. The binding constant for the interaction of ligand, $\mathbf{L}_{1}$, in the presence of $\mathrm{Hg}^{2+}$ ion were calculated using absorption spectra (See experimental section). ${ }^{10}$ The binding constant for the formation of the $\mathbf{L}_{\mathbf{1}}: \mathrm{Hg}^{2+}\left(K_{11}\right)$ and $\mathbf{L}_{1}: \mathrm{Hg}^{2+}\left(K_{12}\right)$ complexes are $3.3 \times 10^{4} \mathrm{M}^{-1}$, and $=6.2 \times 10^{3} \mathrm{M}^{-1}$, respectively.

The complexation and interaction in solution with $\mathrm{Hg}(\mathrm{II})$
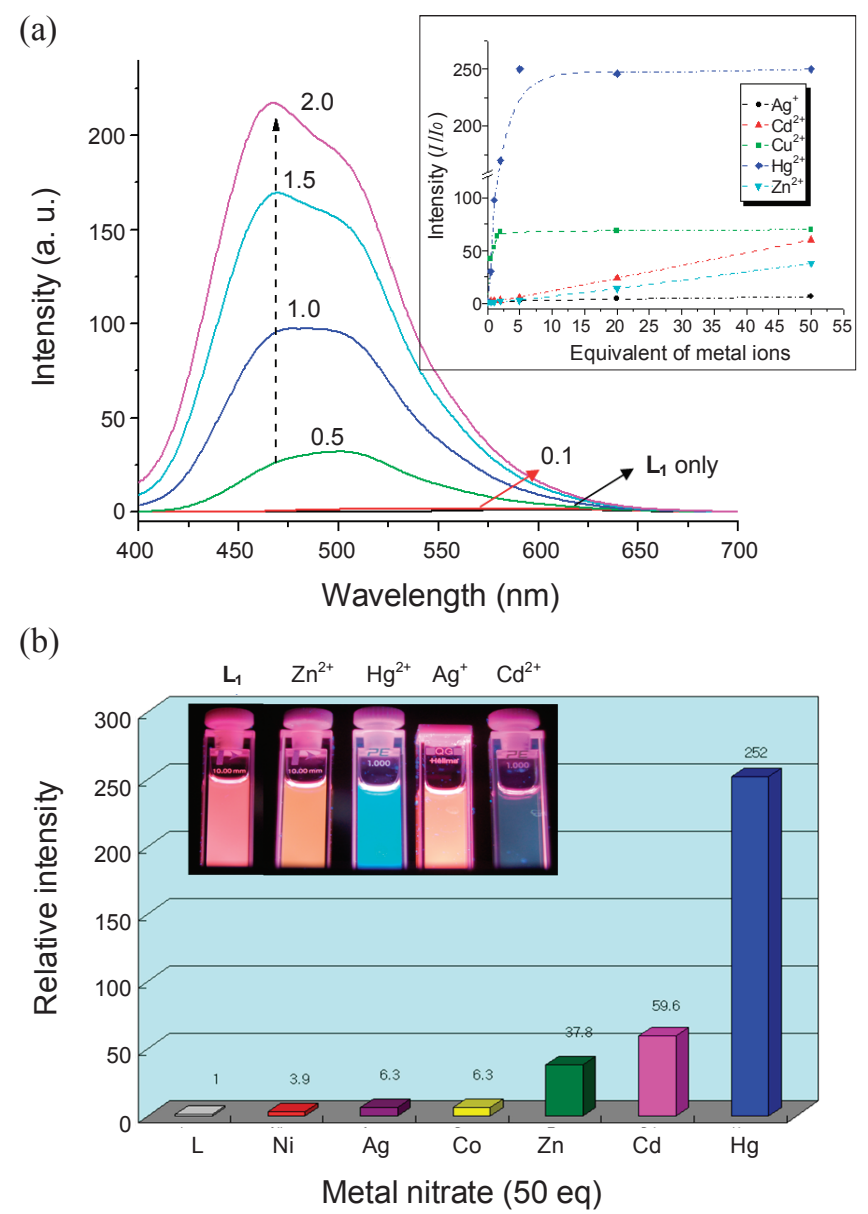

Figure 2. (a) Fluorescent intensity of $\mathbf{L}_{1}$ in $\mathrm{CH}_{3} \mathrm{CN}$ upon addition of $\mathrm{Hg}^{2+}(0.1 \sim 2.0$ equiv. $)$. Inset: $I / I_{0}$ vs equivalent of metal $\left(\mathrm{Hg}^{2+}, \mathrm{Cd}^{2+}\right.$, $\mathrm{Zn}^{2+}, \mathrm{Ni}^{2+}, \mathrm{Co}^{2+}$, and $\mathrm{Ag}^{+}$) ions curve. (b) Fluorescent response of $\mathbf{L}_{1}$ in the presence of various metal ions (50 equiv.) in $\mathrm{CH}_{3} \mathrm{CN}$.

ion were investigated by ${ }^{1} \mathrm{H}-\mathrm{NMR}$, because ligand $\mathbf{L}_{\mathbf{1}}$ was the most effective and selective for this metal ion. Therefore, excess $\mathrm{Hg}\left(\mathrm{NO}_{3}\right)_{2}$ in $\mathrm{CD}_{3} \mathrm{OD}$ were added to a $0.05 \mathrm{M}$ solution of $\mathbf{L}_{\mathbf{1}}$ in the same solvent. The ${ }^{1} \mathrm{H}-\mathrm{NMR}$ spectra of the resulting solutions measured at ambient temperature, 15 min after addition of $\mathrm{Hg}(\mathrm{II})$. As shown in Figure 3, well resolved peaks originated from the alkyl and aryl group of $\mathbf{L}_{\mathbf{1}}$ were observed. An increase in the mercury ion concentration gradually downfield-shifted the proton resonance of $\mathrm{H} 9\left(\mathrm{H}^{\prime}\right)$ and $\mathrm{H} 10\left(\mathrm{H}_{10}{ }^{\prime}\right)$ from the azacrownether segment, the former being the most affected. This observation strongly suggests that $\mathrm{Hg}$ (II) is coordinated via the nitrogen atom as well as oxygen atoms. The spectrum resolution of azacrownethter region decreases in the presence of metal ion, implying that a fluxional conformation were formed and/or the fast equilibrium between $1: 1\left(\mathrm{~L}_{1}: \mathrm{M}^{2+}\right)$ and $1: 2\left(\mathrm{~L}_{1}: \mathrm{M}^{2+}\right)$ complexes occurs in solution.

Additional evidence of coordination modes is to investigate fluorescence change of $\mathbf{L}_{1}$ in the presence of $\mathrm{H}^{+}$ion. If the nitrogen atoms in azacrownether were still strongly coupled to the metal ions in the excited state, then one would expect the fluorescence of $\mathbf{L}_{1}: 2 \mathrm{M}^{2+}$ to be very similar to that of $\mathbf{L}_{1}: 2 \mathrm{H}^{+}$. The emission spectrum of the protonated $\mathbf{L}_{1}$ resembles that of $\mathbf{L}_{1}$ at high $\left[\mathrm{Hg}^{2+}\right]$, where a large fraction of the $1: 2\left(\mathbf{L}_{1}: \mathrm{Hg}^{2+}\right)$ 


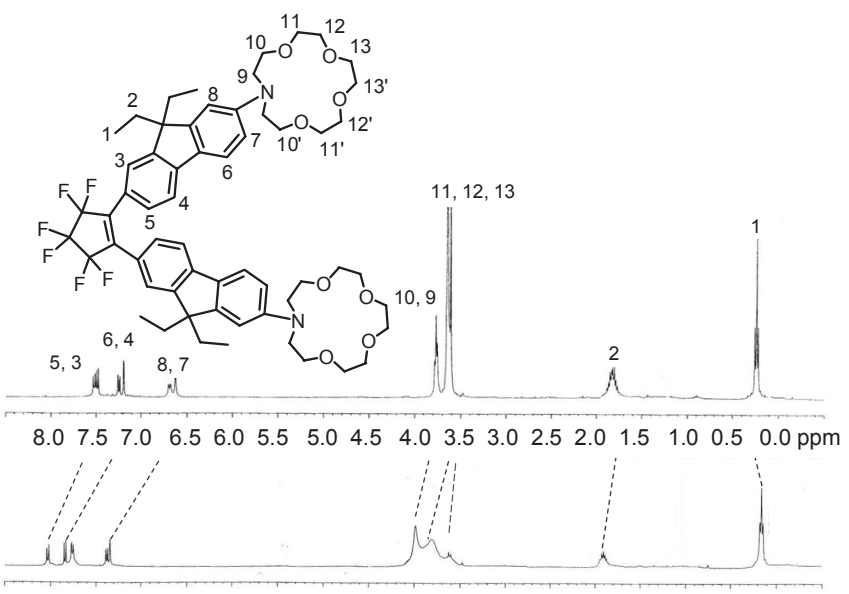

$\begin{array}{llllllllllllllllll}8.0 & 7.5 & 7.0 & 6.5 & 6.0 & 5.5 & 5.0 & 4.5 & 4.0 & 3.5 & 3.0 & 2.5 & 2.0 & 1.5 & 1.0 & 0.5 & 0.0 & \text { ppm }\end{array}$

Figure 3. Change of ${ }^{1} \mathrm{H}-\mathrm{NMR}$ spectra for ligand $\mathbf{L}_{\mathbf{1}}$ (top) and after adding excess $\mathrm{Hg}^{2+}$ ion in $\mathrm{CD}_{3} \mathrm{OD}(400 \mathrm{MHz})$.

complex is present (See supporting information).

The similarity of the spectra of $\mathbf{L}_{\mathbf{1}}$ in the protonated form and in the 1:2 complex with $\mathrm{Hg}^{2+}$ is consistent with the nitrogen lone pair not interacting significantly with the $\pi$-system upon ion binding. Such similarities in the absorption and emission spectra of the ion-bound form of the aza-crown chromophores and the protonated dye or a modified dye in which the crown is replaced by a hydrogen have been observed for other aza-crown ether substituted systems. ${ }^{11}$ Thus, it appears two different experiments, NMR and fluorescence measurement, may have concluded that the complex was formed by the strong coordination of O-N-O donor set in azacrownether moiety and metal ion. In summary, a novel fluorene and perfluorocyclopentene based ligand $\mathbf{L}_{\mathbf{1}}$ with $\mathrm{NO}_{4}$ donor set was synthesized and was evaluated as fluorimetric sensor for $\mathrm{Ni}^{2+}, \mathrm{Ag}^{+}, \mathrm{Co}^{2+}$, $\mathrm{Zn}^{2+}, \mathrm{Cd}^{2+}$, and $\mathrm{Hg}^{2+}$. This ligand exhibits enhanced fluorescence intensity upon addition of all metal ions through the CHEF effect and the formation of 1:2 complexes. In particular, ligand $\mathbf{L}_{1}$ has been demonstrated highly selectivity and sensitivity for the $\mathrm{Hg}^{2+}$ ion due to the strong interactions between NO donor set and metal ion. It is highly recommended to put consistent effort in the development of derivatives of this kind, because starting material, compound $\mathbf{2}$, has high photoluminescence quantum efficiency and characteristic for ease of varied receptors introduced into fluorene segments.

\section{Experimental Section}

General consideration. All reagents were purchased from commercial sources and without further purification unless otherwise noted. All solvent were freshly distilled from appropriate drying agents prior to use. Conventional schlenk techniques were used, and reactions were carried out under dry nitrogen atmosphere. ${ }^{1} \mathrm{H}$ NMR Spectra were recorded with a Bruker advance $300 \mathrm{MHz}$ or $400 \mathrm{MHz}$ spectrometer instrument. The absorption and photoluminescence spectra were recorded on a Perkin-Elmer Lambda 2S UV-visible spectrometer and a Perkin LS fluorescence spectrometer, respectively. 2-Bromo-9,9-diethyl-7-iodofluorene (1) was prepared according to literature procedures $^{9}$ as follows: Bromination of 9,9-diethylfluorene was conducted using $N$-bromo succinimide (NBS), and the resulting 2-bromo-9,9-diethylfluorene intermediate was treated with acetic acid, water, concentrated sulfuric acid, iodine, and iodic acid in carbon tetrachloride to afford 2-bromo-9,9-diethyl-7iodofluorene.

Binding constant determination. The binding constant of $\mathbf{L}_{1}$ for $\mathrm{Hg}$ (II) was determined by using previous method. ${ }^{12}$ The following equations describe the equilibrium constants for the formation of 1:1 $\left(\mathbf{L}_{1}: \mathrm{Hg}\right)$ and 1:2 $\left(\mathbf{L}_{1}: \mathrm{Hg}_{2}\right)$ complexes,

$$
\begin{array}{lll}
\mathrm{L}+\mathrm{M} & \stackrel{k_{11}}{\rightleftharpoons} \mathrm{LM} \\
\mathrm{LM}+\mathrm{M} \stackrel{k_{12}}{\rightleftharpoons} \mathrm{LM}_{2}
\end{array}
$$

where $\mathrm{L}$ is the ligand, $\mathrm{M}$ is the metal ion, $\mathrm{LM}$ and $\mathrm{LM}_{2}$ are the complexes, and $K_{11}$ and $K_{12}$ is the binding constant. $K_{11}$ and $K_{12}$ can be determined from measurements of absorbance as a function of ion concentration using the following equation

$$
\begin{aligned}
\Delta A / L= & \left\{\left[\mathrm{L}_{\mathrm{t}}\right] K_{11} \Delta \varepsilon_{11}[\mathrm{M}]\right\} /\left\{1+K_{11}[\mathrm{M}]\right\} \\
\Delta A / L= & \left\{\left[\mathrm{L}_{\mathrm{t}}\right]\left(K_{11} \Delta \varepsilon_{11}[\mathrm{M}]+K_{11} K_{12} \Delta \varepsilon_{12}[\mathrm{M}]^{2}\right)\right\} / \\
& \left\{1+K_{11}[\mathrm{M}]+K_{11} K_{12}[\mathrm{M}]^{2}\right\}
\end{aligned}
$$

In equation $3, \Delta A$ is the difference in absorbance at a particular wavelength between the pure dye solution and the solution of dye and metal ion $\left(A_{0}-A\right), L$ is the path length, $\left[\mathrm{L}_{\mathrm{t}}\right]$ is the total ligand concentration, $[\mathrm{M}]$ is the concentration of the free metal, and $\Delta \varepsilon_{11}$ is the change in extinction coefficient at the measurement wavelength between the ligand and the L:metal complex $\left(\varepsilon_{L}-\varepsilon_{L M}\right)$. In equation $4, \Delta \varepsilon_{12}$ is the change in extinction coefficient at the measurement wavelength between the ligand and the 1:2 (L:metal) complex $\left(\varepsilon_{\mathrm{L}}-\varepsilon_{\mathrm{LM} 2}\right)$. These consideration and treatment are valid if the free metal ion concentration is not significantly altered by binding.

Synthesis of 1,2-bis(7-bromo-9,9-diethylfluoren-2-yl)-3,3, 4,4,5,5-hexafluorocyclo pentene (2). A solution of $n$-BuLi (2.34 mmol, 1.6 $\mathrm{M}$ in hexane) was added slowly to the 2-bromo-9,9diethyl-7-iodofluorene $(1 \mathrm{~g}, 2.34 \mathrm{mmol})$ in THF $(100 \mathrm{~mL})$ at $-78^{\circ} \mathrm{C}$ and stirred for $60 \mathrm{~min}$. To this solution was added octafluorocyclopentene $(0.56 \mathrm{~mL}, 1.4 \mathrm{mmol})$. Upon addition of octafluorocyclopentene to the lithiated solutions, the color changed rapidly from pale yellow to brown. The reaction mixture was warmed slowly to ambient temperature and stirred overnight. The reaction mixture was poured into water and repeatedly extracted with $\mathrm{CH}_{2} \mathrm{Cl}_{2}(30-50 \mathrm{~mL})$. The combined organic layer was dried over $\mathrm{MgSO}_{4}$, filtered, and concentrated under reduced pressure. The pure corresponding compounds were isolated by chromatographic workup (silica). Yield: $41 \%$ (eluent: hexane, $\left.R_{f}=0.6\right)$; MS (EI): $m / z 774[\mathrm{M}]^{+} .{ }^{1} \mathrm{H}-\mathrm{NMR}\left(\mathrm{CDCl}_{3}\right.$, $300 \mathrm{MHz}) \delta 7.52-7.20$ (12H, m), 1.73 (8H, q, $J=7.4 \mathrm{~Hz}), 0.17$ $(12 \mathrm{H}, \mathrm{t}, J=7.2 \mathrm{~Hz})$. Anal. Calcd for $\mathrm{C}_{39} \mathrm{H}_{32} \mathrm{Br}_{2} \mathrm{~F}_{6}: \mathrm{C}, 60.48 ; \mathrm{H}$, 4.16. Found: C, 60.22; H, 4.05.

Synthesis of 1,2-bis $\{9,9-$ diethyl-7-(1,4,7,10-tetraoxa-13azacyclopentadecane)fluoren-2-yl $\}-3,3,4,4,5,5$-hexafluoro- 
cyclopentene $\left(\mathbf{L}_{1}\right)$. The mixture of compound 2 ( $0.3 \mathrm{~g}, 0.41$ mmol), 1-aza-15-crown-5 (0.2 g, 0.9 mmol), 2-dicyclohexylphosphino-2'-( $N, N$-dimethylamino)biphenyl $(0.019 \mathrm{~g}, 0.05$ $\mathrm{mmol}), \mathrm{Pd}_{2}(\mathrm{dba})_{3}(0.008 \mathrm{~g}, 0.008 \mathrm{mmol})$, and sodium tert-butoxide $(0.11 \mathrm{~g}, 1.1 \mathrm{mmol})$ was placed in a dried Schlenk tube and dissolved in toluene $(5 \mathrm{~mL})$. The reaction mixture was heated at $80{ }^{\circ} \mathrm{C}$ with stirring for $24 \mathrm{~h}$. The reaction mixture was then cooled to room temperature, taken up in dichloromethane $(60 \mathrm{~mL})$, filtered through Celite, and concentrated in a vacuum. The crude product was purified by flash column chromatography on alumina (neutral) using ethyl acetate and hexane as an eluting solvent. Yield: $25 \%$ (eluent: ethylacetate/hexane (4/1), $\left.R_{f}=0.53\right) ;{ }^{1} \mathrm{H}-\mathrm{NMR}\left(\mathrm{CDCl}_{3}, 300 \mathrm{MHz}\right) \delta 6.47-7.41(12 \mathrm{H}, \mathrm{m})$, $3.74(8 \mathrm{H}, \mathrm{m}), 3.57(32 \mathrm{H}, \mathrm{m}), 1.7(8 \mathrm{H}, \mathrm{q}, J=6.8 \mathrm{~Hz}), 0.21(12 \mathrm{H}$, $\mathrm{t}, J=7.2 \mathrm{~Hz}) .{ }^{13} \mathrm{C}-\mathrm{NMR}\left(\mathrm{CDCl}_{3}, 75 \mathrm{MHz}\right) \delta 150.9,150.5,149.5$, $149.0,141.6,140.8,140.2,128.4,128.0,127.0,126.5,123.9$, $122.9,120.1,114.8,114.1,71.2,70.1,69.8,69.5,56.5,33.2$, 8.9. Anal. Calcd for $\mathrm{C}_{59} \mathrm{H}_{72} \mathrm{~F}_{6} \mathrm{~N}_{2} \mathrm{O}_{8}$ : C, 67.47; H, 6.90. Found: C, 67.13; H, 6.76.

Supporting Information. Emission spectra of compound 2 and $\mathbf{L}_{1}$; photo of emission change for $\mathbf{L}_{1}$; Free $\mathbf{L}_{1}$ in the presence of $\mathrm{Hg}^{2+}$ and $\mathrm{H}^{+}$; fluorescent intensity change of $\mathbf{L}_{\mathbf{1}}$ in the presence of $\mathrm{Cd}^{2+}$ and $\mathrm{Ag}^{+}(0 \sim 5.0 \mathrm{eq})$; fluorescent intensity change of $\mathbf{L}_{1}$ in the presence of $\mathrm{Zn}^{2+}, \mathrm{Ni}^{2+}$, and $\mathrm{Co}^{2+}(0 \sim 5.0 \mathrm{eq}$ or $0 \sim 2 \mathrm{eq}$ ); absorption spectra of $\mathbf{L}_{\mathbf{1}}$ and $\mathbf{L}_{1}: \mathrm{Hg}^{2+}$ in $\mathrm{CH}_{3} \mathrm{CN}$ are available on request from the correspondence author (E-mail: kangy@kangwon.ac.kr; Fax:82-33-242-9598).

Acknowledgments. This work was supported by the Korea Research Foundation Grant funded by the Korean Government (MOEHRD, Basic Research Promotion Fund) (KRF-2008331-C00153).

\section{References}

1. (a) Renzoni, A.; Zino, F.; Franchi, E. Environ. Res. Sect. A 1998, 77, 68. (b) Tchounwou, P. B.; Ayensu, W. K.; Ninashvili, N.; Sutton, D. Environ. Toxicol. 2003, 18, 149.

2. (a) Santos, J. S.; Guardia, M.; Pastor, A.; Santos, M. L. P. Talanta 2009, 80, 207. (b) Feng, L.; Chen, Z. Sens. Actuators B 2007, 122 , 600

3. (a) Czarnik, A. W. Fluorescent Chemosensors for Ion and Molecule Recognition, ACS Symposium Series, Chapter 1, 1993; Vol. 538. (b) Nolan, E. M.; Lippard, S. J. Chem. Rev. 2008, 108, 3443. (c)
Silva, A. P.; Gunaratne, H. Q. N.; Gunnlaugsson, T.; Huxley, A. J. M.; McCoy, C. P.; Rademacher, J. T.; Rice, T. E. Chem. Rev. $1997,97,1515$.

4. (a) Bradshaw, J. S.; Izatt, R. M. Acc. Chem. Res. 1997, 30, 338. (b) Zhang, X.-X.; Buchwald, S. L. J. Org. Chem. 2000, 65, 8027. (c) Chemosensors of Ion and Molecular Recognition; Desvergne, J.-P., Czarnik, A. W., Eds.; Kluwer Academic: Dordrecht, the Netherlands, 1997.

5. (a) Kadarkaraisamy, M.; Sykes, A. G. Polyhedron 2007, 26, 1323 and references therein. (b) Jeon, H. L.; Choi, M. G.; Choe, J.-I.; Chang, S.-K. Bull. Korean Chem. Soc. 2009, 30, 1093. (c) Chartres, J. D.; Davies, M. S.; Lindoy, L. F.; Meehan, G. V.; Wei, G. Inorg. Chem. Commun. 2006, 9, 751. (d) Lee, H.; Lee, S. S. Org. Lett. 2009, 11, 1393. (e) Lee, S. J.; Jung, J. H.; Seo, J.; Yoon, I.; Park, K.-M.; Lindoy, L. F.; Lee, S. S. Org. Lett. 2006, 8, 1641.

6. (a) Prodi, L.; Bargossi, C.; Montalti, M.; Zaccheroni, N.; Su, N.; Bradshaw, J. S.; Izatt, R. M.; Savage, P. B. J. Am. Chem. Soc. 2000, 122, 6769. (b) Kim, K. S.; Jun, E. J.; Kim, S. K.; Choi, H. J.; Yoo, J.; Lee, C.-H.; Hyun, M. H.; Yoon, J. Tetrahedron Lett. 2007, 48, 2481.

7. (a) Song, K. C.; Kim, M. H.; Kim, H. J.; Chang, S.-K. Tetrahedron Lett. 2007, 48, 7464. (b) Hu, Z.-Q.; Yang, X.-D.; Cui, C.-L.; Ding, L.; Lin, C.-S.; Lu, H.-Y.; Wang, L. Sens. Actuators B: Chem. 2009, doi:10.1016/j.snb.2009.11.020. (c) Gunnlaugsson, T.; Bichell, B.; Nolan, C. Tetrahedron 2004, 60, 5799. (d) Gunnlaugsson, T.; Bichell, B.; Nolan, C. Tetrahedron Lett. 2002, 43, 4989.

8. (a) Han, M.; Lee, S.; Jung, J.; Park, K.-M.; Kwon, S.-K.; Ko, J.; Lee, P. H.; Kang, Y. Tetrahedron 2006, 62, 9769. (b) Jung, H.; Kim, K.; Lee, S.; Hwang, H.; Park, K.; Kim, J.; Kwon, S.-K.; Kang, Y. Bull. Korean Chem. Soc. 2007, 28, 1807. (c) Jung, S. O.; Zhao, Q.; Park, J.-W.; Kim, S. O.; Kim, Y.-H.; Oh, H.-Y.; Kim, J.; Kwon, S.-K.; Kang, Y. Org. Electron. 2009, 10, 1066. (d) Kim, D.-H.; Hong, C.-K.; Lee, P. H.; Kang, Y. Bull. Korean Chem. Soc. 2008, 29, 2270. (e) Lee, S. J.; Park, K.-M.; Yang, K.; Kang, Y. Inorg. Chem. 2009, 48, 1030. (f) Lee, H.; Kim, J.; Kang, Y. Inorg. Chem. Commun. 2007, 10, 731. (g) Kang, Y.; Moon, S.-T.; Park, S.; Kim, J.; Lee, S. S.; Park, K.-M. Bull. Kor. Chem. Soc. 2007, 28, 873. (h) Ko, S.; Choi, H.; Kang, M.-S.; Hwang, H.; Ji, H.; Kim, J.; Ko, J.; Kang, Y. J. Mater. Chem. 2010, 20, 2391.

9. Kannan, R.; He, G. S.; Yuan, L.; Xu, F.; Prasad. P. N.; Dombroskie, A. G.; Reinhardt, B. A.; Baur, J. W.; Vaia, R. A.; Tan, L.-S. Chem. Mater. 2001, 13, 1896.

10. Connors, K. A. Binding Constants: The Measurement of Molecular Complex Stability; John Wiley and Sons: New York, 1987.

11. (a) MacQueen, D. B.; Schanze, K. S. J. Am. Chem. Soc. 1991, 113, 6108. (b) Fery-Forgues, S.; Le Bris, M.-T.; Guette, J.-P.; Valeur, B. J. Phys. Chem.1988, 92, 6233. (c) Bourson, J.; Valeur, B. J. Phys. Chem. 1989, 93, 3871.

12. Pond, S. J. K.; Tsutsumi, O.; Rumi, M.; Kwon, O.; Zojer, E.; Brédas, J.-L.; Marder, S. R.; Perry, J. W. J. Am. Chem. Soc. 2004, 126, 9291. 